Utah State University

DigitalCommons@USU

1989

\title{
Growth of nitrogen-fertilized and thinned quaking aspen (Populus tremuloides Michx.)
}

Donald A. Perala

P.R. Laidly

Follow this and additional works at: https://digitalcommons.usu.edu/aspen_bib

Part of the Forest Sciences Commons

\section{Recommended Citation}

Perala, Donald A.; Laidly, P. R. 1989. Growth of nitrogen-fertilized and thinned quaking aspen (Populus tremuloides Michx.). Research Paper North Central Forest Experiment Station, USDA Forest Service.

This Article is brought to you for free and open access by the Aspen Research at DigitalCommons@USU. It has been accepted for inclusion in Aspen Bibliography by an authorized administrator of DigitalCommons@USU. For more information, please contact

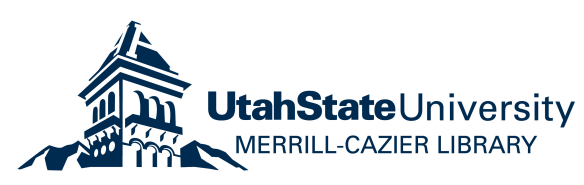


United States

Department of Agriculture

Forest

Service

North Central

Forest Experiment

Station

Research

Paper NC-286

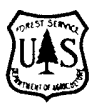

Growth of

Nitrogen-Fertilized

and Thinned

Quaking Aspen

(Populus tremuloides Michx.)

Donald A. Perala and Paul R. Laidly

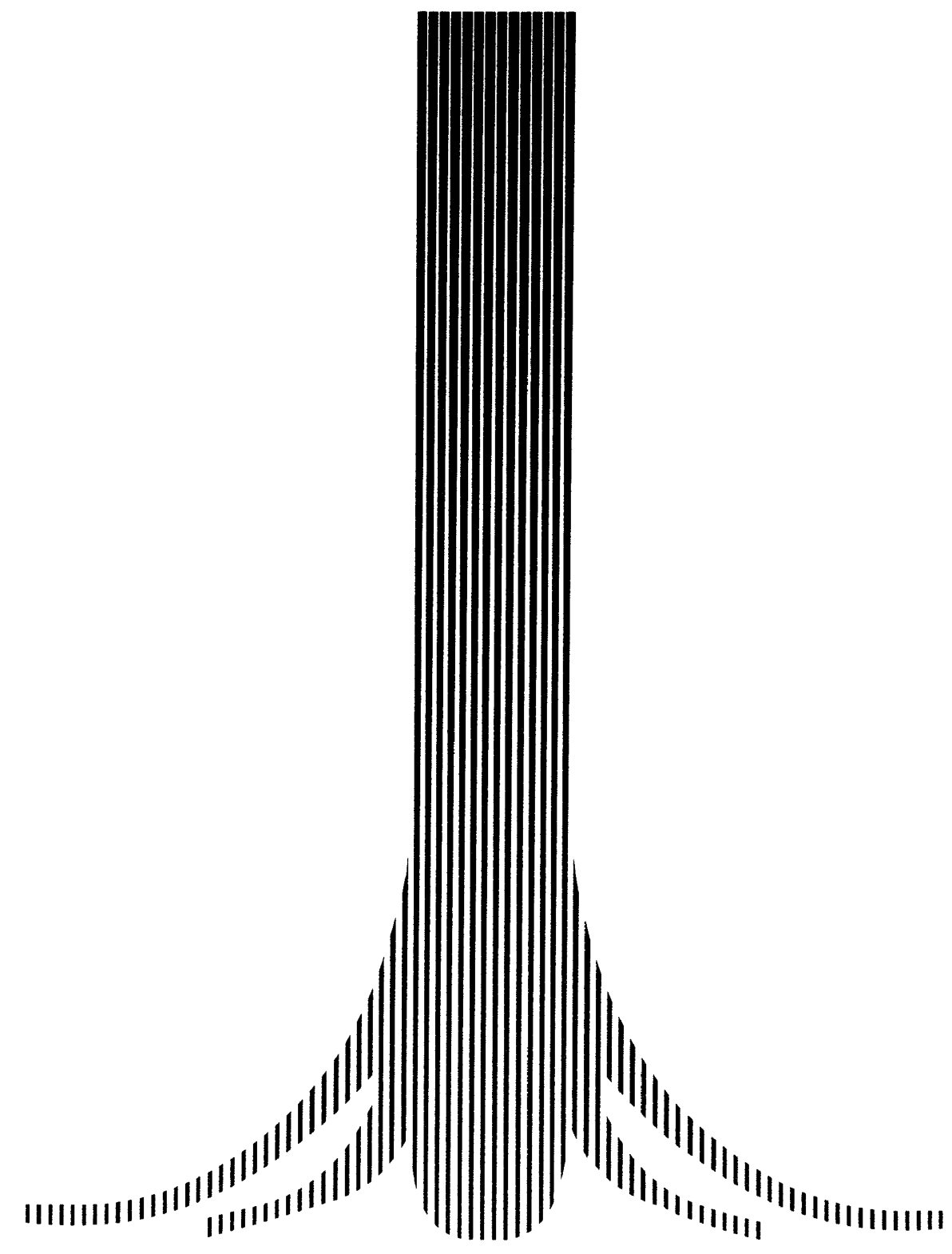


North Central Forest Experiment Station Forest Service--U.S. Department of Agriculture 1992 Folwell Avenue

St. Paul, Minnesota 55108

Manuscript approved for publication June 6, 1989 1989 


\title{
Growth of Nitrogen-Fertilized and Thinned Quaking Aspen (Populus tremuloides Michx.)
}

\author{
Donald A. Perala and Paul R. Laidly
}

Crop trees of quaking aspen (Populus tremuloides Michx.) and its Eurasian equivalent, $P$. tremula L., grow faster after thinning. Thinning first at about age 10 to 15 years accelerates diameter growth the most (Day 1958; Steneker 1966, 1969, 1974; Perala 1978; Langhammer 1979; Schmiedel 1982; Kairyukshtis et al. 1985), although 5- to 7-year-old stands can also benefit (Hubbard 1972, Bella 1975). Newly initiated stands ( 1 to 3 years old) may need more time to express dominance (Perala 1984) before they can respond (Sorensen 1968, Bella 1975). One or two more thinnings up to age 30 prolong rapid growth (Perala 1978, Schmiedel 1982, Kairyukshtis et al. 1985). Stands older than 30 years respond little to thinning (Pike 1953, Schlaegel 1972, Perala 1978).

Aspen has responded little to added phosphorus, potassium, or calcium, but has grown 33 to 177 percent faster when fertilized with nitrogen (Van Cleve and Oliver 1982, Heinonen 1983, Harris et al. 1984, Safford and Czapowskyj 1986, Berguson and Perala 1988). Rates of 150 to $450 \mathrm{lbs} /$ acre are needed, and the response lasts 3 to 10 years or more. One study reported aspen fertilized with NPK $(0,100$, or $200 \mathrm{lbs} /$ acre each) in factorial with thinning (unthinned, 300 , or 600 trees/acre). The fertilizer increased 5 -year growth by 15 to 30 percent; thinning increased it by 15 to 70 percent (Doucet and Veilleux 1982).

Donald A. Perala is a Principal Silviculturist with the North Central Forest Experiment Station, Grand Rapids, Minnesota and Paul R. Laidly is Leader, Management Systems Group, North Central Forest Experiment Station, St. Paul, Minnesota.
The primary objective of thinning and fertilizing aspen is to produce marketable material quickly. Rotations for sawtimber can be shortened by as much as 20 years by thinning (Steneker 1974, Perala 1978, Schmiedel 1982). Wood quality is improved because decay caused by the fungus, Phellinus tremulae (Bond.) Bond. et Boriss, has less time to develop. The fungus enters from dead occluded branches that can be controlled by frequent entries to maintain about 70 percent stocking (Il'in 1981) and by pruning (Kostylev 1976). Total bolewood yields can be increased by 10 to 37 percent by capturing anticipated mortality in thinnings and maintaining stands at near-optimum stocking for growth (Day 1958, Steneker 1974, Perala 1978, Hocker 1982, Kairyukshtis et al. 1985).

We report here a study in aspen that yielded large responses to thinning, but ambiguous and smaller responses to nitrogen fertilizer.

\section{STUDY AREA}

We installed the study in aspen sapling stands near Toivola (St. Louis County) and Greaney (Koochiching County) in north-central Minnesota. The climate is humid, with warm summers and cold winters. Annual temperature and precipitation average $38.5^{\circ} \mathrm{F}$ and 26.6 inches, respectively.

Both stands regenerated by root suckers after the parent stands were clearcut for aspen sawtimber and pulpwood during the winters of 1966-1967 (Greaney) and 1971-1972 (Toivola). The associated tree species were paper birch (Betula papyrifera Marsh.), balsam fir (Abies balsamea (L.) Mill.), and balsam poplar (Populus 

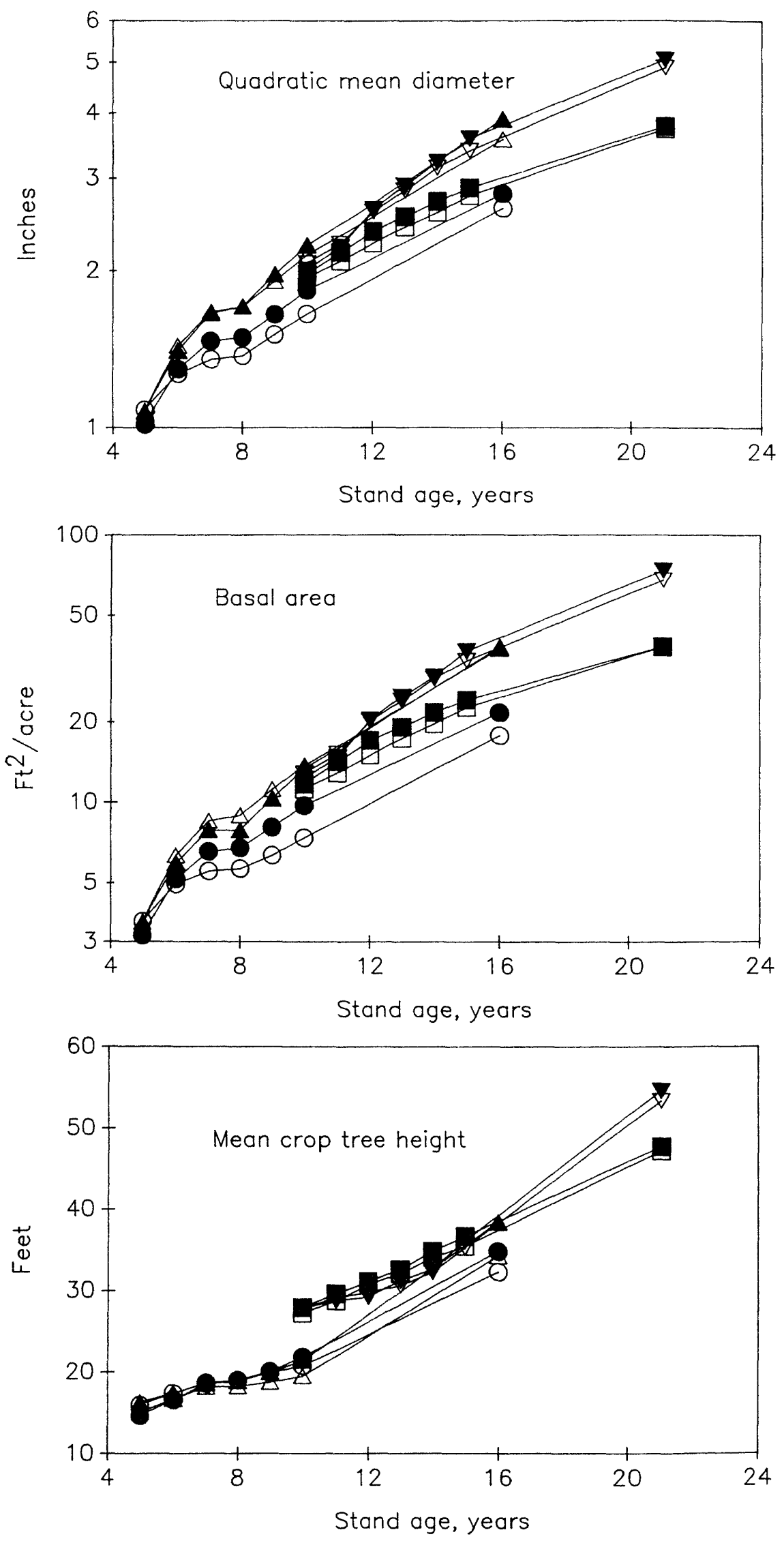

Figure 1.-Crop tree growth at Toivola (circles and triangles) and Greaney (squares and inverted triangles). Squares and circles are unthinned; shaded symbols are fertilized. Note logarithmic scales for diameter, basal area, and volume. 

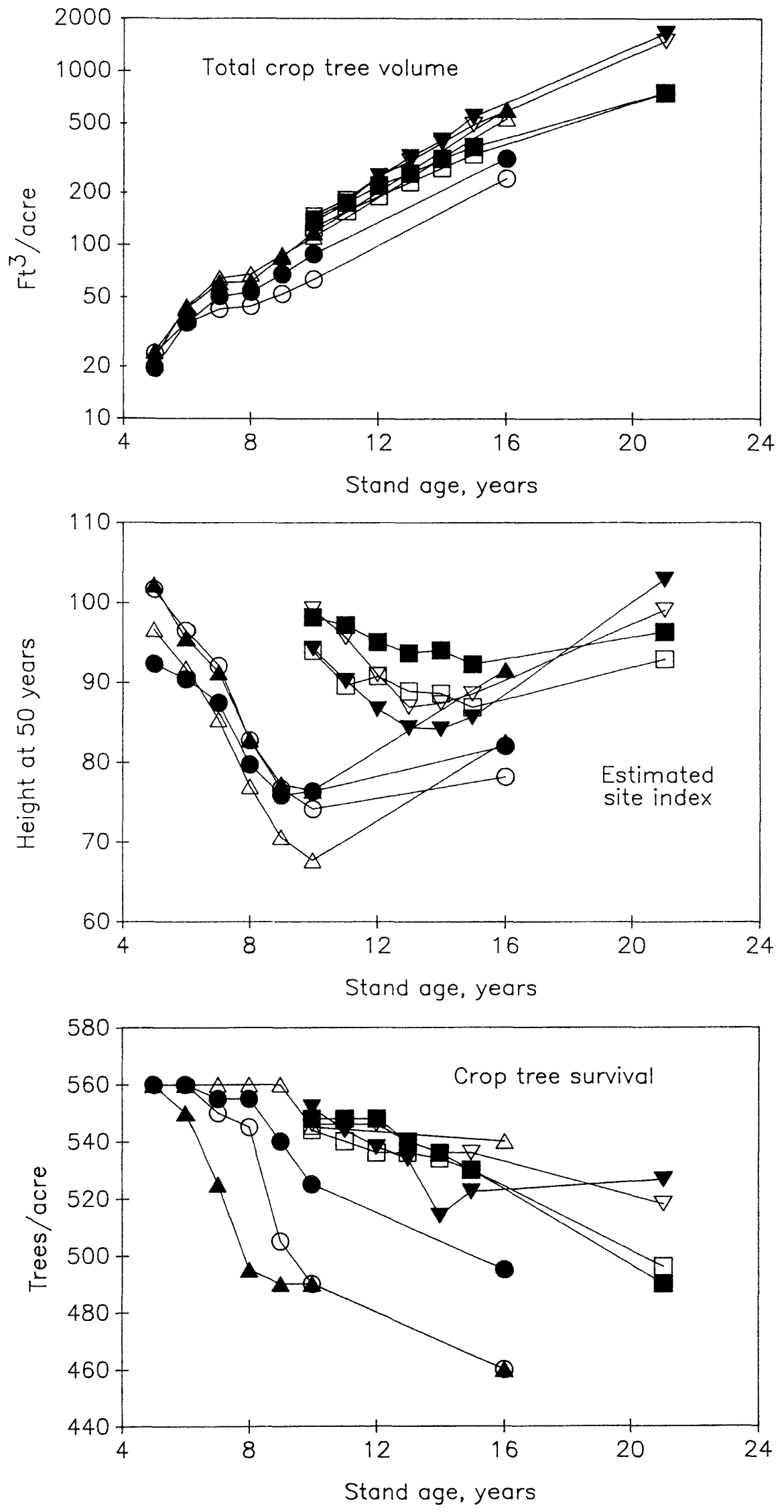
balsamifera L.). The solls were unnamed welldrained clay loams considered excellent for growing aspen. Water tables were about 8 feet deep.

\section{METHODS}

In early spring of 1977 , we established $161 / 5-$ acre circular treatment plots in 5-year-old saplings $(11,500 \pm 2,400$ stems/acre $)$ at Toivola and 20 plots in 10 -year-olds $(5,500 \pm 2,000 /$ acre $)$ at Greaney. Dominant and co-dominant potential crop trees (550/acre) were permanently numbered with tree marking paint on circular measurement plots $(0.05$ acre at Toivola; 0.1 acre at Greaney) centered on the treatment plots. Four treatments replicated four times (Tolvola) or five times (Greaney) were applied in a randomized design:

1. no treatment (control),

2. fertilize with $150 \mathrm{lb}$ nitrogen per acre as $\mathrm{NH}_{4} \mathrm{NO}_{3}$,

3 . thin to leave the crop trees, and

4. fertilize and thin (treatments 2 and 3 ).

Diameter at breast height of crop trees was measured to the nearest 0.1 inch with steel diameter tapes and total height of 8 to 10 crop trees per plot was measured to the nearest 0.1 foot with a fiberglass pole in spring 1977, annually after each of the first 5 years' growth, and after 11 years. Crop tree injury and disease were also recorded. The Tolvola area was defoliated by the forest tent caterpillar (Malacosoma disstria Hubner) in 1979. Two replications at Greaney were destroyed by beavers in 1981 .

Tree measurement summaries gave plot values for trees per acre; net basal area (B) and mortality basal area, $\mathrm{ft}^{2} /$ acre; and quadratic mean d.b.h. (D), inch. Mean plot height (H) was determined by regression (Appendix). Total volume under bark (V), $\mathrm{ft}^{3} /$ acre, was derived from the product, $\mathrm{BxH}$, according to Schlaegel (1975). Significant treatment effects were determined by ANCOVA of derived plot volume (Appendix). Plot site index was estimated (Gevorkiantz 1956, Lundgren and Dolid 1970) each year from the three tallest trees on each plot.
Table 1.-Eleven-year net growth by study site and treatment

\begin{tabular}{lcccc}
\hline Treatment & Basal area & Diameter & Helght & Volume \\
\hline & FP/ac & In. & $F t$ & $F t^{3} / a c$ \\
& & Toivola & & \\
& & 1.6 & 16 & 220 \\
Control & 14 & 1.8 & 20 & 300 \\
N-fertilize & 18 & 2.5 & 19 & 510 \\
Thin & 34 & 2.8 & 22 & 580 \\
Thin+N & 34 & & & \\
& & Greaney & & \\
Control & 27 & 1.8 & 20 & 630 \\
N-fertilize & 27 & 1.8 & 20 & 620 \\
Thin & 55 & 2.8 & 26 & 1,340 \\
Thin $+\mathrm{N}$ & 60 & 3.0 & 27 & 1,500 \\
\hline
\end{tabular}

\section{RESULTS AND DISCUSSION}

Thinning, and to a lesser extent, $\mathrm{N}$-fertilizer, accelerated both diameter and height growth of aspen crop trees (table 1, fig. 1). Significantly more volume was produced by the larger crop trees, especially those thinned and fertilized at Greaney (table 2). Allowing for the covariate initial volume, thinning added $42 \mathrm{ft}^{3} /$ acre/year bolewood ( +56 percent) to crop trees at Greaney and $30 \mathrm{ft}^{3} /$ acre/year (+189 percent) to crop trees at Toivola.

Table 2.-Parameters for the equation for predicted volume, $V_{p}=a V_{o}^{b}$, reconstituted from unweighted least squares linear regression' solutions of Eq. [7] (Appendix)

\begin{tabular}{llll}
\hline \multirow{2}{*}{ Site } & Treatment & \multicolumn{2}{c}{ Parameter } \\
\cline { 3 - 4 } Toivola & Control & $182 \times 10^{-3}$ & $\mathbf{b}$ \\
& N-fertilize & $335 \times 10^{-1}$ & 2.243 \\
& Thin & 292 & 0.761 \\
& Thin $+\mathrm{N}$ & 383 & 0.193 \\
Greaney & Control & $127 \times 10^{-5}$ & 0.145 \\
& N-fertilize & $503 \times 10^{-1}$ & 2.747 \\
& Thin & $693 \times 10^{-1}$ & 0.556 \\
& Thin $+\mathrm{N}$ & $712 \times 10^{-1}$ & 0.613 \\
& & & 0.631 \\
\hline
\end{tabular}

1 For Toivola, $n=16, s_{y \cdot x}=76 \mathrm{ft}^{3}, R^{2}=0.972$
For Greaney, $n=20, s_{y \cdot x}=113 \mathrm{ft}^{3}, R^{2}=0.992$ 
Covarlate adjusted response to $\mathrm{N}$ was modest, but consistent, in combination with thinning. Without thinning, response was mixed:

$\begin{array}{lcc}\text { Site } & \begin{array}{c}\text { Thinned } \\ \mathrm{Ft}^{3} / \text { acre/year }\end{array} & \begin{array}{c}\text { Unthinned } \\ \text { (percent) }\end{array} \\ \text { Toivola } & +6(+13) & +15(+91) \\ \text { Greaney } & +16(+14) & -17(-22)\end{array}$

Growth response to thinning and $\mathrm{N}$ pales in comparison to the effects of just 1 year's defoliation by the forest tent caterpillar. By interpolation, growth loss in height, diameter, and volume was 72,81 , and 87 percent, respectively (fig. 1). Growth rates completely recovered the next year.

Calculated site index differed widely over the study period, especially at Toivola (fig. 1). Existing site index curves are obviously inadequate for very young stands. At age 15, estimated site index for the controls is 87 at Greaney and 77 at Toivola. These are valid relative, but not absolute, estimates of site index.

Crop tree mortality was acceptable at Greaney, but troubling at Tolvola (table 3, fig. 1). Hypoxylon mammatum (Wahl.) Mill. was the primary agent. After 11 years, 4.5 percent of the crop trees were infected at Toivola, but only 1.2 percent at Greaney (table 4). Treatment was not a factor; the infection rate in the controls was lowest at one site but highest at the other. Clonal variation in disease resistance (Copony and Barnes 1974) may override treatment effects, but there also may be treatment, site, and age interactions that we do not yet understand.

Table 3.- Total number and basal area of trees that died over the first 5 years by site and treatment

\begin{tabular}{|c|c|c|c|c|}
\hline \multirow[b]{2}{*}{ Treatment } & \multicolumn{2}{|c|}{ Stems } & \multicolumn{2}{|c|}{ Basal area } \\
\hline & Toivola & Greaney & Toivola & Greaney \\
\hline & \multicolumn{2}{|c|}{ Per acre } & \multicolumn{2}{|c|}{ Ft/acre } \\
\hline Control & 70 & 14 & 0.51 & 0.34 \\
\hline$N$-fertilize & 35 & 18 & .22 & .40 \\
\hline Thin & 15 & 10 & .29 & .32 \\
\hline Thin $+\mathrm{N}$ & 70 & 30 & .80 & 1.02 \\
\hline
\end{tabular}

Table 4.-The infection rate of aspen crop trees by HypoxyIon mammatum after 11 years by site and treatment

\begin{tabular}{lrc}
\hline Treatment & Tolvola & Greaney \\
\hline \multicolumn{2}{c}{ Percent } \\
& \multicolumn{3}{c}{} \\
Control & 0.0 & 2.0 \\
N-fertilize & 4.0 & 1.7 \\
Thin & 11.0 & 1.2 \\
Thin $+\mathrm{N}$ & 3.3 & 0.0 \\
\hline
\end{tabular}

\section{CONCLUSIONS}

Quaking aspen responded to thinning and Nfertilizer much as reported elsewhere. Our ambiguous site/thin/ $\mathrm{N}$ interaction is puzzling and adds little to our understanding of how aspen responds to fertilizer. Although nutrient response is usually smaller on fertile sites than on deficient sites (Allen 1987), we cannot attribute the $\mathrm{N}$-response differences to site quality because site and age are confounded and neither is replicated.

Height growth commonly increases in fertilizer studies but is seldom affected by thinning. Ralston (1954) and Dahms (1971) report two exceptions, in red pine (Pinus resinosa Ait.) and lodgepole pine ( $P$. contorta Dougl.), where height growth improved after thinning on droughty sites. Quaking aspen is especially sensitive to water deficit (Sucoff 1982) so that improved height growth is possible through water conservation by density control.

Hypoxylon canker threatens the thinned trees at Toivola but not at Greaney. We do not know if the risk can be attributed to stand age, site quality, or clonal character. Much more work is needed to enable better selection of hypoxylonresistant stands for thinning.

\section{ACKNOWLEDGMENTS}

We thank Diamond International Corporation and Potlatch Corporation for providing the study sites. Dr. Edwin White, then of the University of Minnesota, and his graduate assistants applied the fertilizer. 


\section{LITERATURE CITED}

Allen, H.L. 1987. Forest fertilizers. Journal of Forestry. 85(2): 37-46.

Bella, I.E. 1975. Growth-density relations in young aspen sucker stands. Inf. Rep. NORX-124. Edmonton, Canada: Northern Forest Research Centre, Canadian Forestry Service. $12 \mathrm{p}$.

Berguson, W.E.; Perala, D.A. 1988. Aspen fertilization and thinning: research results and future potential. In: Ek, A.R.; Hoganson, H.M., eds. Proceedings, Minnesota timber supply: perspectives and analysis. Minnesota Agricultural Experiment Station Scientific Journal Series. 16,671: 176-183.

Copony, J.A.; Barnes, B.V. 1974. Clonal variation in the incidence of Hypoxylon canker in trembling aspen. Canadian Journal of Botany. 52: 1475-1481.

Dahms, W.G. 1971. Growth and soil moisture in thinned lodgepole pine stands. Res. Pap. PNW-127. Portland, OR: U.S. Department of Agriculture, Forest Service, Pacific Northwest Forest and Range Experiment Station. $32 \mathrm{p}$.

Day, M.W. 1958. Thinning aspen in upper Michigan. Michigan Agricultural Experiment Station Quarterly Bulletin. 41: 311-320.

Doucet, R.; Vellleux, J.M. 1982. Recherche et developpement sur le peuplier. XVIII Resultats quinquennaux de traitments d'eclaircie et de fertllization dans les peupleraies naturelles de diverses classes d'age. [Poplar research and development. XVIII - Five-year results of thinning and fertilization treatments in natural poplar stands of various age classes.] No. 76. Quebec, Canada: Memoire, Service de la Recherche (Terres et Forets). $57 \mathrm{p}$.

Gevorkiantz, S.R. 1956. Site index curves for aspen in the Lake States. Tech. Note LS464. St. Paul, MN: U.S. Department of Agriculture, Forest Service, Lake States Forest Experiment Station. 2 p.

Harris, A.R.; Urie, D.H.; Cooley, J.H. 1984. Sludge fertilization of pine and aspen forests on sand soils in Michigan. In: Stone, E.L., ed. Forest solls and treatment impacts: Proceedings, 6th North American soils conference; 1983 June; Knoxville, TN. Knoxville, TN: University of Tennessee, Department of Forestry, Wildlife, and Fisheries: 193-206.

Heinonen, T. 1983. Haavikon lannoituskoe. Summary: a fertilization experiment in a
Populus tremula stand. Silva Fenn. 17(1): 65-70.

Hocker, H.W. 1982. Effects of thinning on biomass growth in young Populus tremuloides plots. Canadian Journal of Forest Research. 12: 731-737.

Hubbard, J.W. 1972. Effects of thinning on growth and yield. In: Aspen symposium proceedings. Gen. Tech. Rep. NC-1. St. Paul, MN: U.S. Department of Agriculture, Forest Service, North Central Forest Experiment Station: 126-130.

Il'in, A.M. 1981. [Thinning of aspen forests.] Lesovodstvo, Lesnye Kul'tury i Pochvovedenie No. 10: 55-58. (In Russian, cited in Forestry Abstracts. 46: 1214.)

Kairyukshtis, L.A.; Yuodval'kis, A.I.; Ionikas, Yu.V.; Barkauskas, A.P. 1985. [Thinnings and current increment of stands.] Lesnoe Khozyaistvo No. 11: 32-36. (In Russian, cited in Forestry Abstracts. 47: 3988.)

Kostylev, A.S. 1976. [Growing high-grade aspen from young natural stands.] Lesnoe Khozyaistvo No. 12: 58-60. (In Russian, cited in Forestry Abstracts. 38: 5723.)

Langhammer, A. 1979. Tynningsmodeller for osp - og litt om nye veier $i$ forskning pa bestandspleien. Norsk Skogbruk No. 6/7: $7,8,19$.

Lundgren, A.L.; Dolid, W.A. 1970. Biological growth functions describe published site index curves for Lake States timber species. Res. Pap. NC-36. St. Paul, MN: U.S. Department of Agriculture, Forest Service, North Central Forest Experiment Station. 9 p.

Perala, D.A. 1978. Thinning strategies for aspen: a prediction model. Res. Pap. NC161. St. Paul, MN: U.S. Department of Agriculture, Forest Service, North Central Forest Experiment Station. $19 \mathrm{p}$.

Perala, D.A. 1984. How endemic injuries affect early growth of aspen suckers. Canadian Journal of Forest Research. 14: 755-762.

Pike, R.T. 1953. Thinning aspen, Duck Mountain Forest Reserve, Manitoba. Silvic. Leafl. 89. Winnipeg, Manitoba: Canadian Department or Resources and Development, Forestry Branch, Division of Forest Research. $3 \mathrm{p}$.

Ralston, R.A. 1954. Some effects of stand density on the height growth of red pine on poor sites in northern lower Michigan. Papers of the Michigan Academy of Science, Arts, and Letters. 39: 159-165. 
Safford, L.O.; Czapowskyj, M.M. 1986. Fertilizer stimulates growth and mortality in a young Populus-Betula stand: 10-year results. Canadian Journal of Forest Research. 16: 807-813.

Schlaegel, B.E. 1972. Growth and yield of managed stands. In: Aspen symposium proceedings. Gen. Tech. Rep. NC-1. St. Paul, MN: U.S. Department of Agriculture, Forest Service, North Central Forest Experiment Station: 109-112.

Schlaegel, B.E. 1975. Estimating aspen volume and weight for individual trees, diameter classes, or entire stands. Gen. Tech. Rep. NC-20. St. Paul, MN: U.S. Department of Agriculture, Forest Service, North Central Forest Experiment Station. 16 p.

Schmiedel, H. 1982. Aspenanbau in Holzzuchtplantagen. [Intensive silviculture of aspen.] Sozialistische Forstwirtschaft. 32: 338-340.

Sorensen, R.W. 1968. Size of aspen crop trees little affected by initial sucker density. Res. Note NC-51. St. Paul, MN: U.S. Department of Agriculture, Forest Service, North Central Forest Experiment Station. 4 p.

Steneker, G.A. 1966. Thinning aspen Riding Mountain. Inf. Rep. MS-X-2. Winnipeg, Manitoba: Canadian Department of Forestry, Forestry Research Lab. 12 p.

Steneker, G.A. 1969. Multiple thinning in fourteen-year-old poplar, Porcupine Provincial Forest, Saskatchewan. Inf. Rep. MS$\mathrm{X}-17$. Winnipeg, Manitoba: Department of Fisheries and Forestry, Forestry Branch. $19 \mathrm{p}$.

Steneker, G.A. 1974. Thinning of trembling aspen (Populus tremuloides Michaux) in Manitoba. Inf. Rep. NOR-X-122. Edmonton, Alberta: Canadian Forestry Service, Northern Forestry Research Centre. 17 p.

Stewart-Oaten, A.; Murdoch, W.W. 1986. Environmental impact assessment: "pseudoreplication" in time? Ecology. 67: 929940.

Sucoff, E. 1982. Water relations of the aspens. Tech. Bull. 338. St. Paul, MN: University of Minnesota, Agricultural Experiment Station. 6 p.

Sullivan, A.D.; Reynolds, M.R., Jr. 1976. Regression problems from repeated measurements. Forest Science. 22: 382-385.
Van Cleve, K.; Oliver, L.K. 1982. Growth response of postfire quaking aspen (Populus tremuloides Michx.) to $\mathrm{N}, \mathrm{P}$ and $\mathrm{K}$ fertilization. Canadian Journal of Forest Research. 12: 160-165.

Weisberg, S. 1985. Applied linear regression, second edition. New York, NY: John Wiley \& Sons. $324 \mathrm{p}$.

\section{APPENDIX}

\section{Numerical Analysis}

Mean plot height $(\mathrm{H}$, for tree $\mathrm{D})$, $\mathrm{ft}$, was estimated from height:d.b.h. equations of the form,

$$
\mathrm{H}=\mathrm{aD}^{\mathrm{b}} \text {. }
$$

These were derived from plot-by-plot regression analyses of the linearized log-log model of Eq. [1],

$$
\ln h t=a+b(\ln d b h)+e_{i},
$$

where

ht=total tree height,

$\mathrm{dbh}=$ tree d.b.h.,

$a, b=e s t i m a t e d$ coefficients, and

$e_{1}=$ error.

Standard errors averaged about 5 percent of total tree height (table 5).

Table 5.- Height equations $\left(H=a D^{\infty}\right)$ mean accuracy by site

\begin{tabular}{|c|c|c|c|}
\hline \multirow[b]{2}{*}{ Treatment } & \multicolumn{2}{|c|}{ Standard error } & \multirow[b]{2}{*}{$\mathbf{R}^{2}$} \\
\hline & Feet & Percent & \\
\hline \multicolumn{4}{|c|}{ Toivola } \\
\hline Control & 0.96 & 4.64 & 0.744 \\
\hline$N$-fertilize & 1.07 & 5.42 & 0.610 \\
\hline Thin & 0.97 & 4.71 & 0.726 \\
\hline Thin $+\mathrm{N}$ & 0.99 & 4.73 & 0.686 \\
\hline \multicolumn{4}{|c|}{ Greaney } \\
\hline Control & 1.53 & 4.40 & 0.433 \\
\hline$N$-fertilize & 1.64 & 4.72 & 0.548 \\
\hline Thin & 1.66 & 5.08 & 0.499 \\
\hline Thin $+\mathrm{N}$ & 1.42 & 4.27 & 0.310 \\
\hline
\end{tabular}
and treatment 
Standing plot volume with respect to age can be described by the model:

$$
\mathrm{V}=\mathrm{aA} \mathrm{A}^{\mathrm{b}} \mathrm{A}^{\mathrm{A}}
$$

where

$\mathrm{A}=$ stand age, years, and

$\mathrm{a}, \mathrm{b}, \mathrm{c}=$ parameters to be estimated.

The value of the parameters will differ if treatment or site alters curve shape (determined by parameters $b$ and $c$ ) or rate (a). These parameters were estimated for each plot (ignoring initial observations that were used later as covariates) from the linearized form of Eq. [3],

$$
\ln V=\ln a+b(\ln A)+(\ln c) A+e_{1}
$$

The fit statistics for this model were extremely good (table 6). Because parameters $b$ and $c$ are correlated with $\mathrm{a}$, predicted present volume $\left(\mathrm{V}_{\mathrm{p}}\right)$ for each plot, rather than the coefficients, was the variable used to test treatment effects. $V_{p}$ is analogous to computed plot mean volume over years and avoids the serial correlation problem common to growth series analysis (Sullivan and Reynolds 1976, Stewart-Oaten and Murdoch 1986). $V_{p}$ was an unbiased and precise estimator of present volume (table 7).

Table 6. - Volume growth equations $\left(V=a A^{b} c^{A}\right)$ mean statistics. Note that $A^{b}$ was not significant at Toivola and $C^{A}$ was not significant at Greaney.

\begin{tabular}{lcccc}
\hline & \multicolumn{3}{c}{ Parameters } \\
\cline { 2 - 4 } Treatment & $\mathbf{a}$ & $\mathbf{b}$ & $\mathbf{C}$ & $\mathbf{R}^{2}$ \\
\hline & \multicolumn{4}{c}{ Toivola } \\
Control & 10.4 & 0.0 & 1.21 & 0.978 \\
$\mathrm{~N}$-fertilize & 10.2 & 0.0 & 1.24 & .993 \\
Thin & 10.0 & 0.0 & 1.28 & .991 \\
Thin $+\mathrm{N}$ & 8.4 & 0.0 & 1.30 & .988 \\
& & & & \\
& & Greaney & & \\
Control & 0.454 & 2.41 & 1.00 & .996 \\
N-fertilize & 0.791 & 2.25 & 1.00 & .996 \\
Thin & 0.077 & 3.23 & 1.00 & .998 \\
Thin $+\mathrm{N}$ & 0.059 & 3.37 & 1.00 & .996 \\
\hline
\end{tabular}

Table 7.-Unweighted least squares linear regression of $V=a+b V_{p}\left(n=34, R^{2}=.998, s_{y x}=21.4 \mathrm{ft}^{3} / \mathrm{acre}\right)$

\begin{tabular}{cccc}
\hline Predictor & Coefficient & Student's t & Probability \\
\hline a & 7.600 & 1.1 & 0.28 \\
b & 1.000 & 132.1 & 0.00 \\
\hline
\end{tabular}

The effect of treatment on $V_{p}$ was determined by analysis of covariance (ANCOVA). Treatment response commonly depends on variation of the experimental unit, in this case initial plot volume. Our postulated nonlinear model is

$$
\mathrm{V}_{\mathrm{p}}=\mathrm{aV}_{\mathrm{o}}^{\mathrm{b}},
$$

where

$$
\mathrm{V}_{\mathrm{o}}=\text { initial value of } \mathrm{V} \text { (covariate). }
$$

The expanded model to accommodate treatment effects is

$$
\mathrm{V}_{\mathrm{p}}=\mathrm{aV}_{\mathrm{o}}^{\mathrm{b}} \mathrm{c}^{\mathrm{F}} \mathrm{d}^{\mathrm{T}}
$$

having dummy variables $(0,1)$ for

$$
\begin{aligned}
& \mathrm{F}=\text { fertilized, and } \\
& \mathrm{T}=\text { thinned. }
\end{aligned}
$$

Note that model (6) can be collapsed to model (5) having unique values for parameter $\{a\}$ and, if treatment interacts with the covariate, parameter $\{b\}$.

ANCOVA was conducted by regression of the $\log -\log$ transformation of model (6),

$$
\begin{aligned}
& \ln V_{p}=\ln a+b\left(\ln V_{o}\right)+(\ln c) F+(\ln d) T \\
& +(\text { all interactions })+e_{i} .
\end{aligned}
$$

Logarithmic transformations were used because they provided linear relations and stabilized variance. (The Toivola variance was nearly twice that of Greaney, so that a pooled analysis was not appropriate.) The best subset method using Mallow's Cp criteria determined variables retained in all final equations (Weisberg 1985). 
Perala, Donald A.; Laidly, Paul R.

1989. Growth of nitrogen-fertilized and thinned quaking aspen (Populus tremuloides Michx.). Res. Pap. NC-286. St. Paul, MN: U.S. Department of Agriculture, Forest Service, North Central Forest Experiment Station. 8 p. Reports the results of a thinning/fertilizing experiment in juvenile aspen stands.

KEY WORDS: Malacosoma disstria, Hypoxylon mammatum, mortality, volume growth. 